\title{
Learning and Service Quality in Islamic Higher Education of Minority Muslim Bali
}

\author{
Ismail Suardi Wekke \\ Sekolah Tinggi Agama Islam Negeri (STAIN) Sorong \\ Sorong, Indonesia \\ iswekke@gmail.com
}

\begin{abstract}
The development of education, especially universities, both public and private is required to always develop science and technology. Therefore, the function of higher education is very strategic in improving the quality of resources, both human resources and infrastructure of education. Higher education institutes are required to always make changes towards more advanced education, independent and qualified in accordance with the demands of the change of global environment rapidly. This research was conducted in Sekolah Tinggi Agama Islam Denpasar, Bali. This paper discusses the implementation of education should look at the quality of service. Educational activities are not only oriented towards the final result the educational process, but also by proving good accountability include quality assurance, quality control, and quality improvement. Finally, the efforts to integrate the academic and religious culture should be the idol of all academicians particularly at the Islamic higher education. This research strongly supports the multiple socio-political circumstances at this time to give an opportunity to the Islamic higher education in order to further develop in the future.
\end{abstract}

Keywords: quality, satisfaction, higher education

\section{INTRODUCTION}

The success of university in increasing students' satisfaction will be able to maintain the number of applicants for new students that the university will continue to grow and develop sustainably [1]. University as one of the service organization is currently experiencing a fundamental change. This change is not only due to the rapid development of science, technology and information, but also because of changes in society's expectations toward the role of universities in the future. Such activity can be implemented if the institution has the following resources: (1) students (2) reputation; (3) adequate facilities and infrastructure; (4) financing (funding) [2][3][4]. Theoretically, the customers' loyalty or students is influenced by several factors such as learning, service quality and satisfaction.

The universities need to be aware of the importance of education service quality. Good service quality is able to improve customers' satisfaction [5] [6] [7]. This means that the ability of universities to provide a fast and accurate service to students will increase students' satisfaction toward Sekolah Tinggi Agama Islam (STAI) Denpasar. The overall number of students STAI Denpasar experiencing significant growth from 2012 to 2016. This indicates that the more increasing of college competition so that requires STAI Denpasar make improvements in the quality of learning systems and services are expected to provide satisfaction and loyalty to the students.

Not much different from public service provided by the government officials in other institutions. STAI Denpasar as one of the private higher education institute in the province of Bali, still possesses weaknesses. It is characterized by various complaints of students as a learning system that is reflected in the plan of learning where the lecturer does not provide learning guide before the start of the course, the quality of lecturers' teaching which is reflected in the material inconsistency that displayed that has been prepared. In addition, the students' complaint on the service quality of STAI Denpasar as inadequate lecture rooms, less convincing of lecturers Performance and professional administrative staff in providing services to students.

Based on the above empirical phenomena, it is interesting to be assessed further. Therefore, this study takes an object at STAI Denpasar as one of the private colleges that have responsibilities in providing services to students and faculty optimally. STAI Denpasar should be able to provide optimal service concept with the concept of relationship marketing, so that it increases satisfaction as an effort to reach the students' loyalty and improve the working performance at STAI Denpasar.

Relevant research is also carried out [8] [9], they presented variables of lecturers' competence, learning process, student satisfaction, by using analytical methods of path analysis, in which the research shows that the competence of lecturers and learning processes significantly influence student satisfaction, in which it means that the study programs completed by good competence of lecturers and learning process will increase student satisfaction toward those study programs. Partially, from two independent variables, lecturers' competence gives greater influence in improving student satisfaction on the study program than the learning process. The others research was also conducted [10] [11], with the variable quality of academic services, satisfaction, loyalty and data collection methods used is the data collected by using a set of questionnaires that tested the reliability and validity for 30 respondents.

The data were analysed by structural Equation Modelling (SEM) which consists of measurement models and structural models of AMOS version 19 programs. The conclusion of the research explained that the quality of academic services can be explained by factors of physical 
evidence, reliability, and responsiveness, empathy giving the effect of strong and weak collateral effects. The quality of academic services significantly influence the loyalty of students through student satisfaction and the quality of academic services directly affects less significantly on student loyalty. Then, research also conducted [12] [13] with variables of service quality, student satisfaction and collection methods of data collection were a questionnaire using proportional random sampling method. Data analysis techniques using multiple regression, with a view t test and $F$ test results of research show that there is a positive and significant impact on student satisfaction, there is no influence on student satisfaction guarantee, there is a positive and significant impact on student satisfaction, there is positive and significant and responses to student satisfaction.

\section{RESEARCH METHODOLOGY}

This research is an explanatory research which explains the position of the variables that were analysed and the relationship between the variables [14]. The population in this study were students who use the services STAI Denpasar start from the academic year 2010/2011 to 2016/ 2017 amounted to 1114 students, where the amount of sample was adjusted by analysis tool used is the analysis of Structural Equation Model (SEM). This research is composed of four variables and 15 indicators. The number of samples taken from eight times of the number of parameters thus estimated sample size used was 120 respondents [15] [16] [17].

\section{RESULT AND DISCUSSION}

Hypothesis testing confirms that the better the quality of service perceived by the students will increase students' satisfaction at STAI Denpasar. This means that changes in improving the quality of service will improve students' satisfaction at STAI Denpasar. The logic underlying thinking is a student who regards good quality of services provided will increase students' satisfaction. The results of this study reinforced the theory and some results of empirical research that concluded that the quality of service is positive and significant impact on student satisfaction [8] [18].

Their research's results showed that the improvement of service quality will create a stronger satisfaction to the university. So students will be satisfied if STAI Denpasar can deliver services better. [19][20] in general, services are provided to students are the best in the hope the creation of student satisfaction. Creating students' satisfaction through service aims to create a positive image in the hearts of consumers. Satisfaction can also be considered as the relationship between expectation and experience, in which the closer to expectations the more satisfied the consumers are. Giving service that can give satisfaction to the students is not an easy thing, often also found problems in the implementation which makes students uncomfortable.

Therefore, it needs a careful planning and adequate facilities in order to create students' satisfaction. There is a close relationship between service quality and students' satisfaction. Good quality service can make students want to remain enrolled and continue studying at STAI Denpasar and from the relationship, the Chairman of STAI Denpasar can identify the desirability and needs of students, so the head of STAI Denpasar can improve things that can make students happy or satisfied with the services provided.

Based on the results of the confirmatory analysis, it showed the indicators which gave the largest contribution to reflect on the service quality is Assurance. Students today are looking for assurance of an accredited college "B" so that the alumni will not be in trouble in finding a job and adjusting to the rank of goverment officer. In addition students also expect guarantees on the ability of educators and education personnel to provide services which can satisfy students. Therefore, the STAI Denpasar need to maintain accreditation "B" that have been made at this time even attempting to improve its accreditation to "A".

STAI Denpasar also continues to improve the teaching quality of the lecturers by giving greater opportunities to the lecturers who will continue their education to a higher level and give trainings and participation in seminars both locally, nationally and internationally. Everything was done so that the learning process at STAI Denpasar can be even better in the future. The next indicator that gives the largest contribution in explaining the variable quality of service is Responsiveness, the willingness to help the students and provide proper attention. Complaints and service needs students should be able to respond quickly to allow students to feel completely unnoticed by educators and education personnel at STAI Denpasar thus will have an impact on improving students' satisfaction.

Indicators that contribute in reflecting the service quality is Reliability. Reliability in this study refers to the ability to provide the promised service accurately and reliably [21] [22]. Employees should be able to realize the promise that has been delivered to students quickly and accurately so that more students trust toward the employee's ability of STAI Denpasar.

In addition Empathy, includes the care and individual attention to the students also have to be increased by educators and education personnel must be careful to see any problems faced by the students and should be able to resolve the problems [23][24][25]. Another strategy that can be done by STAI Denpasar is continuing to improve the family atmosphere that is built between students, staff and educators so that it is expected that students do not hesitate to deliver their problems to STAI Denpasar.

A further aspect to note is Tangibles that describes physical facilities, equipment, and personnel as well as the appearance and presence of the user. Party of STAI Denpasar needs to continue improving facilities and infrastructure supporting teaching and learning processes such as lecture rooms were comfortable, the availability learning media, free internet service throughout the campus area of STAI Denpasar and the availability of better books at the library. The students as the most important element in educational institutions need to be heard on whether the service that has been provided is in 
accordance with expectations [26][27]. Evaluation of the service quality is necessary to know exactly what is expected, what has been perceived by the students on the quality of service they received. Thus the quality of academic services can serve as the basis for improving the loyalty of students' satisfaction in improving STAI Denpasar.

Recent development shows that the competition for the market (prospective students) in educational institutions is very tight, it is not sufficient to have an excellent physical facilities, but also to be accompanied by the provision of services to make give satisfaction to the students so that it will lead to the loyal students [28][29][4]. Although in this case education is not profit-making organizations, but more and more students are interested in joining in the institution will increase the value of the educational institutions, which in turn will give a good image.

\section{CONCLUSION}

Culture is actually a universal culture. It is owned by everyone who involves themselves in academic activities. Service Quality affects positively and significantly on students' satisfaction. The higher the service quality provided to students, the students' satisfaction at STAI Denpasar will be higher, in order to improve student satisfaction, the company had to provide fast and precise adequate physical facilities to improve the quality of teaching and learning process.

Enhancing academic environment means that culture of students in a consistent, systematic, and continuous in the life of the academic community, both when on campus such as face to face lectures in classroom, laboratory practice, read in the library, and general stadium. Mean while, outside the campus such as seminars, discussions, research and community service.

\section{REFERENCES}

[1] Loo, A., \& Chung, C. W. (2006). A model for information literacy course development: a liberal arts university perspective. Library Review, 55(4), 249-258.

[2] Fantazy, K., \& Abdul Rahim A. Al Athmay, A.-A. (2014). Ethics and religion in higher education. International Journal of Commerce and Management, 24(2), 180-196.

[3] Tyler E. Holmes, M. (2008). Higher education reform in Egypt: preparing graduates for Egypt's changing political economy. Education, Business and Society: Contemporary Middle Eastern Issues, 1(3), 175185

[4] Welch, A. (2012). The limits of regionalism in Indonesian higher education. Asian Education and Development Studies, 1(1), 24-42.

[5] Ab. Halim Tamuri, Mohd Yusof Othman, Jawiah Dakir, Ahmad Munawar Ismail, \& Zakaria Stapa. (2013). Religious education and ethical attitude of Muslim adolescents in Malaysia. Multicultural Education \& Technology Journal, 7(4), 257-274.

[6] Bunyi, G. W. (2013). The quest for quality education: the case of curriculum innovations in Kenya. European Journal of Training and Development, 37(7), 678-691.

[7] Thurab-Nkhosi, D., \& Marshall, S. (2009). Quality Assurance in Education. Quality Assurance in Education, 17(3), 264-280
[8] Bögel, S., Stieglitz, S., \& Meske, C. (2014). Adapting business process redesign concepts to learning processes. Business Process Management Journal, 20(4), 598-614.

[9] Maslovaty, N. (2002). Organizational learning: teachers' perceptions of the "ideal student" trait system. International Journal of Manpower, 23(8), 734-753

[10] Bannan-Ritland, B. (2003). The Role of Design in Research: The Integrative Learning Design Framework. Educational Researcher.

[11] Mohammed-Marzouk, M. R. (2012). Teaching and Learning in Iraq: A Brief History. The Educational Forum, 76(2), 259-264

[12] Coulson-Thomas, C. J. (1997). The future of the organization: the role and contribution of quality. Managing Service Quality, 7(6), 301-306.

[13] Wiklund, P. S., \& Wiklund, H. (1999). Student focused design and improvement of university courses. Managing Service Quality, 9(6), 434-443.

[14] Cohen, L., Manion, L., \& Morrison, K. (2007). Research Methods in Education. Education (Vol. 55). https://doi.org/10.1111/j.14678527.2007.00388_4.x

[15] Cobb, P., Confrey, J., DiSessa, A., Lehrer, R., \& Schauble, L. (2003) Design Experiments in Educational Research. Educational Researcher, 32(1), 9-13.

[16] Smith, J. (2009). Judging research quality: from certainty to contingency. Qualitative Research in Sport and Exercise, 1(2), 91-100.

[17] Winlow, H., Simm, D., Marvell, A., \& Schaaf, R. (2013). Using Focus Group Research to Support Teaching and Learning. Journal of Geography in Higher Education, 37(2), 292-303.

[18] McPherson, M., \& Miguel Baptista Nunes, J. (2002). Supporting educational management through action research. International Journal of Educational Management, 16(6), 300-308

[19] Brewis, G. (2013). Education for service: social service and higher education in India and Britain, 1905-1919. History of Education Review, 42(2), 119-136.

[20] Sudarat Tuntivivat. (2016). The inter-relationship between violence and education amidst armed conflict in southern Thailand. Journal of Aggression, Conflict and Peace Research Iss, 8(4)

[21] Dean, J. (2014). Muslim values and market value: a sociological perspective. Journal of Islamic Marketing, 5(November 2012), 20-32.

[22] Payne, S. (2010). Leadership and spirituality: business in the USA. The International Journal of Leadership in Public Services, 6(2), 68-72.

[23] Mugellesi Dow, R., Bobrinsky, N., Pallaschke, S., Spada, M., \& Warhaut, M. (2006). A knowledge management initiative in ESA/ESOC. Journal of Knowledge Management, 10(2), 22-35

[24] Tran, B. (2008). Paradigms in corporate ethics: the legality and values of corporate ethics. Social Responsibility Journal, 4(1/2), 158-171.

[25] Uddin, E. (2011). Cross-cultural social stress among Muslim, Hindu, Santal and Oraon communities in Rasulpur of Bangladesh. International Journal of Sociology and Social Policy, 31(5/6), 335-360

[26] Leisman, G., Mualem, R., \& Mughrabi, S. K. (2015). The neurological development of the child with the educational enrichment in mind. Psicología Educativa, 21(2), 79-96

[27] Uljens, M. (2015). Curriculum work as educational leadership paradoxes and theoretical foundations. Nordic Journal of Studies in Educational, 22(January 2015), 22-30.

[28] Besara, R., \& Kinsley, K. (2011). Academic libraries - measuring up: assessment and collaboration for student success. New Library World, 112(9/10), 416-424.

[29] McGrath, P. (2007). Knowledge management in monastic communities of the medieval Irish Celtic church. Journal of Management History, 13(2), 211-223. 